\title{
Mongolian “Neolithic” and Early Bronze Age ground stone tools from the northern edge of the Gobi Desert
}

\author{
Joan S. Schneider ${ }^{1}$, Tserendagva Yadmaa ${ }^{2}$, Thomas C. Hart ${ }^{3}$, \\ Arlene M. Rosen ${ }^{4}$, Annelise Spiro ${ }^{5}$ \\ 1. Earthwatch Institute, Inc., California State Parks, Colorado Desert District (retired). 6595 Hawarden Drive, \\ Riverside, CA, USA. Email: joanschn@gmail.com \\ 2. Center for Archaeological Study, Institute of History and Archaeology, Mongolian Academy of Sciences, \\ Ulaanbaatar-51, Mongolia. Email: tserendagva_ya@yahoo.com \\ 3. Environmental Archaeology Laboratory, Department of Anthropology, University of Texas at Austin, 2201 \\ Speedway Stop C3200, Austin, TX 78712, USA. Email: thomas.hart@utexas.edu \\ 4. Department of Anthropology, University of Texas at Austin, 2201 Speedway Stop C3200, Austin TX 78712, \\ USA. Email: amrosen@austin.utexas.edu \\ 5. Freelance Researcher, Limmatalstr.11, 8049 Zurich, Switzerland. Email: alspiro@bluewin.ch
}

\begin{abstract}
:
The transition from the Mongolian Neolithic to the Bronze Age is not well understood. Within Ikh Nart Nature Reserve, over a period of five years, we identified a number of sites with dense surface artefact scatters and features that seem to represent this transition period. Evident in those concentrations are characteristic microblade cores, microblades, "thumbnail" flake scrapers, projectile points, ground stone tools, and stone features of unknown function. Between 2012 and 2014 we collected ground stone artefacts from four sites and sediment samples from three sites. With permission of Mongolian authorities, the artefacts from one site and sediment samples from three sites were sent for botanical analyses to the University of Texas, Austin, Environmental Archaeology Laboratory. Preliminary results indicate that plant remains are present on the ground stone artefacts: dendritic long-cells from a deep pore of one artefact and starch grains from the pores of six of the seven artefacts. These data present the first opportunity to understand what resources "Neolithic" people were processing with ground stone tools in this area and further our opportunity to better understand the little-known "Neolithic"-Early Bronze Age transition period in Central Asia. This paper describes the ground stone artefacts and further explores the results of data retrieved from some of these artefacts.
\end{abstract}

Keywords: ground stone tools; Mongolia; Neolithic; milling stones; Bronze Age; ancient plant residues

\section{Introduction}

The Mongolian "Neolithic" is not well understood and our knowledge regarding its postulated anticipatory position leading to the better known Bronze Age is minimal. Studies

Published by the School of History, Classics and Archaeology, University of Edinburgh ISSN: 2055-0472. URL: http://journals.ed.ac.uk/lithicstudies/

This work is licensed under a Creative Commons Attribution 2.5 UK: Scotland License. 
of the cultures of the Central Asian steppes have neither confirmed nor clarified the economies or relationships among hunter-gathers, more sedentary farmers-collectors, and the development of pastoral nomadic societies. Little "Neolithic" research has been conducted in Mongolia and, in fact, there is little agreement regarding its time frame, while most research has been conducted within the timeframes of more highly visible remnants of later peoples on the landscape. Much more research attention has been given to those of the Bronze Age and Turkic periods, the iconic pastoral nomadic lifestyle, or those sites associated with Mongolia's national identity of armed warriors of the Xiongnu [Hunnu] and Mongolian Empire periods (for example, see Lees \& Bates 1974; Frachetti 2008; Janz 2012). Frachetti (2008:18-22) provides a concise review of models for the emergence of pastoralism in Central Asia. Here we attempt to consider how ground stone tools and palaeobotanical remains may contribute to our understanding of Mongolia's past.

Our archaeological work at Ikh NartinChuulu Nature Reserve (Ikh Nart) in DornogoviAimag (province) of central southeastern Mongolia began in 2010 (Figure 1). Until this date, no systematic archaeological investigations had been conducted in this area of Mongolia. The archaeological project began as an extension of an established wildlife conservation effort by a consortium of Mongolian and American wildlife conservation biologists from the Denver Zoo, Mongolian Academy of Sciences, Anza-Borrego Desert State Park in California, Mongolian Conservation Coalition, Argali Research Center, and the Earthwatch Institute, Inc.

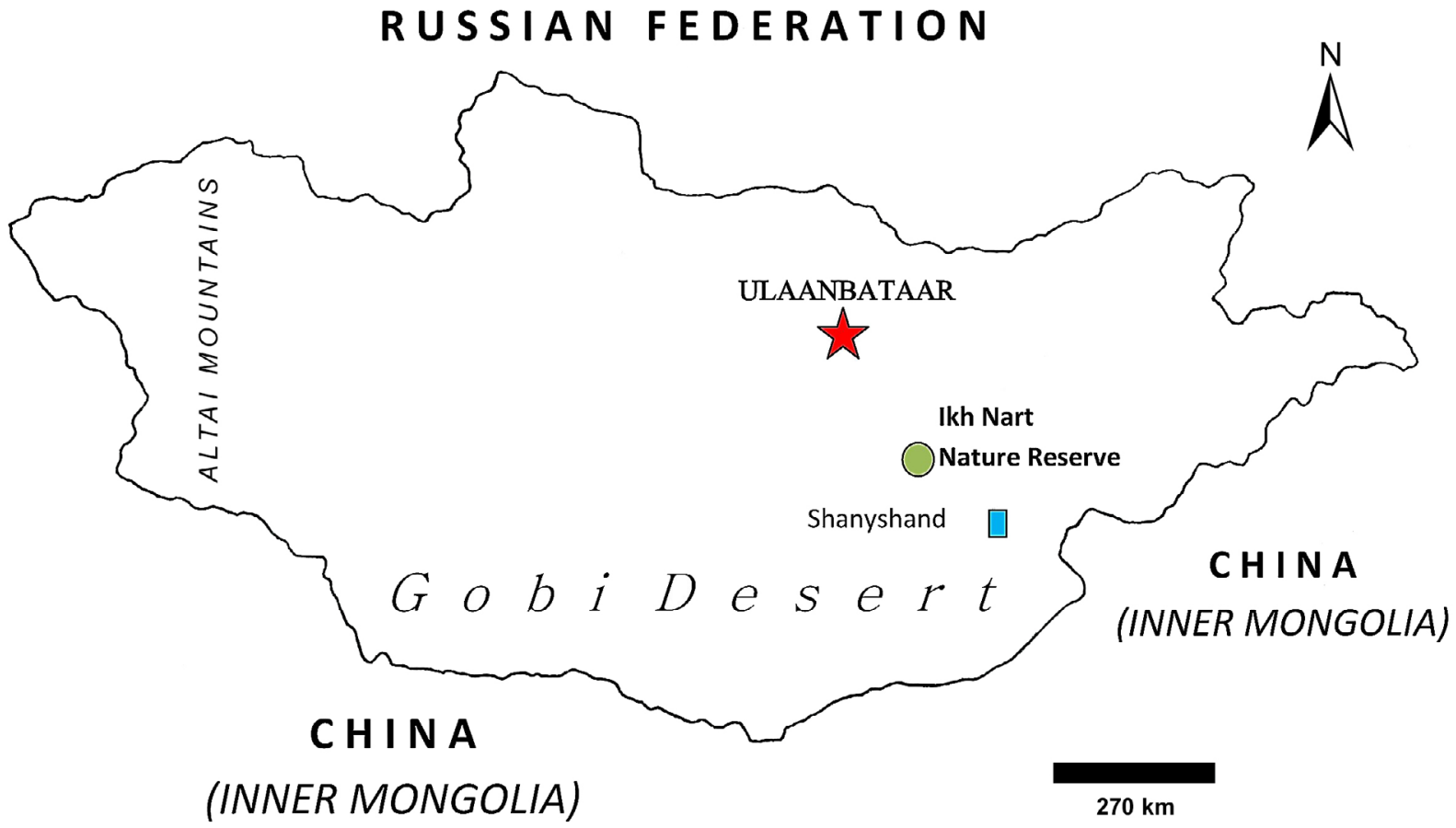

Figure 1. Outline of Mongolia showing location of Ikh Nart Nature Reserve between Ulaanbataar, the capital of Mongolia, and the city of Shanyshand to the south. Major geomorphic provinces of the Gobi Desert and Altai Mountains are shown approximately.

The lead author of this article was invited to participate in the development of a management plan for Ikh Nart that would attempt to include cultural heritage resources. At the time, cultural resources within the Ikh Nart were not understood in terms of locations, site types, or frequency. Previous casual non-systematic observations by wildlife conservation biologists were the only information available. 
With the support of the Earthwatch Institute, an archaeologically oriented team first visited Ikh Nart in 2010. Since then, we have steadily progressed to a point where we more fully understand the cultural resources of the area and the manifestations of cultural heritage (Schneider \& Tserendagva 2013; Schneider \& Tserendagva 2014; Tserendagva et al. 2015) in terms of archaeological site types and projected frequencies of sites within Ikh Nart.

After initial reconnaissance surveys in 2010, a probabilistic (random-sample) pedestrian survey strategy was established. Over the course of four field seasons (2011-2014), we completed intensive pedestrian survey of a 23-block sample in 2014. Preliminary results from the sample data indicate that nearly 5000 archaeological sites exist within Ikh Nart's $>66.000$ hectares. Site types recognized include residential areas, stone-working areas, Bronze Age burial features of several types, Xiongnu (Hunnu), Turkic Period, Kitan, and Mongolian Empire period burial features and burial complexes, as well as ruins of Buddhist communities and religious structures; other sites are present but chronological and cultural affiliations are not yet understood. Prominent among the site types recognized (18\% of sites in sample) are those with artefact assemblages thought to be characteristic of the little-known Mongolian "Neolithic", the focus of this paper (Figure 2). Although burial sites are the most common site type ( $42 \%$ of the sample sites), none of these burials are identified as "Neolithic."

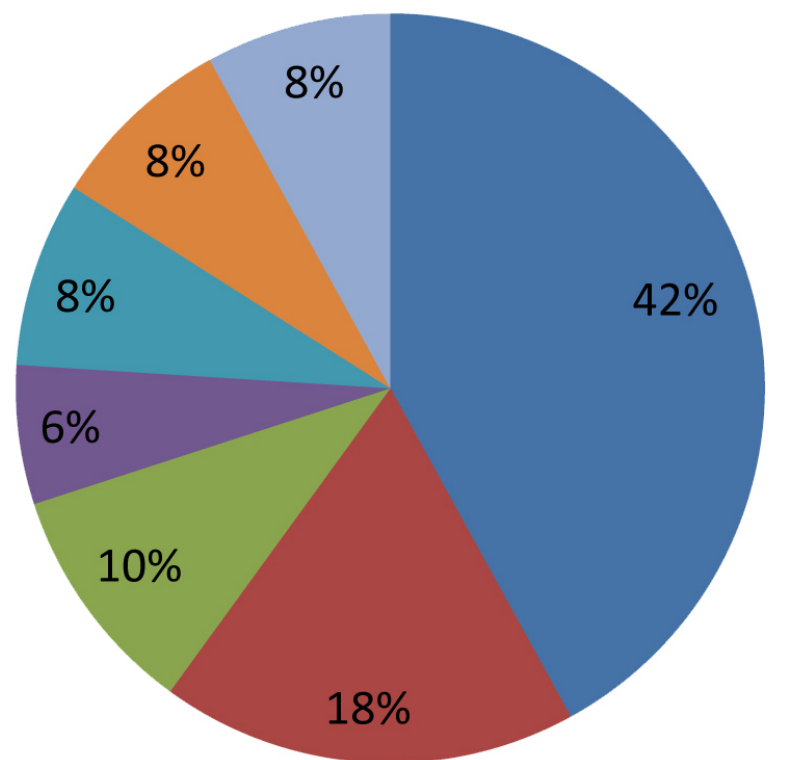

Burials

Neolithic residential scatters

Mixed periods mixed contents artifact scatters

Petroglyphs

\section{Quarry}

\section{Stone constructions of unknown} purpose

Figure 2. Distribution of site types identified at Ikh Nart from the random sample and the projected proportion of those identified as having "Neolithic" assemblages.

Little comparative data are available for the region in which we are working (compare with Günchinsüren 2009; Günchinsüren \& Bazargür 2009). As far as we are aware, no research has been conducted that focuses on plant and animal exploitation strategies in this region. To date, the most extensive work on the Mongolian "Neolithic" of the southern portion of Mongolia is that of Lisa Janz (2012) who examined collections from the Gobi region. Janz proposed a chronology for the circum-"Neolithic” period in the Gobi that we will use in our work. Although our project is focused on management strategies for a Mongolian Protected Area as a model for a United Nations-sponsored Special Protected Area Network (SPAN), Ikh Nart also presents research opportunities in the transitional zone between the Gobi Desert and Steppe environments. We see our work at Ikh Nart as an opportunity to add to the earlier archaeological record of the Mongolian prehistory, that portion of the archaeological record leading toward the emergence of Mongolia's iconic pastoral-nomadic cultures. 


\subsection{The Environmental setting}

Ikh Nart's terrain consists of rolling hills, high rocky outcrops, ephemeral lakes (sometimes containing water from local precipitation), sand dunes, and mostly dry drainages that occasionally contain flowing streams. Low-lying areas appear as marshes in years when there is a great deal of precipitation, but are most often dry with stands of feather grasses (Stipa spp.) (Figures 3 to 5).

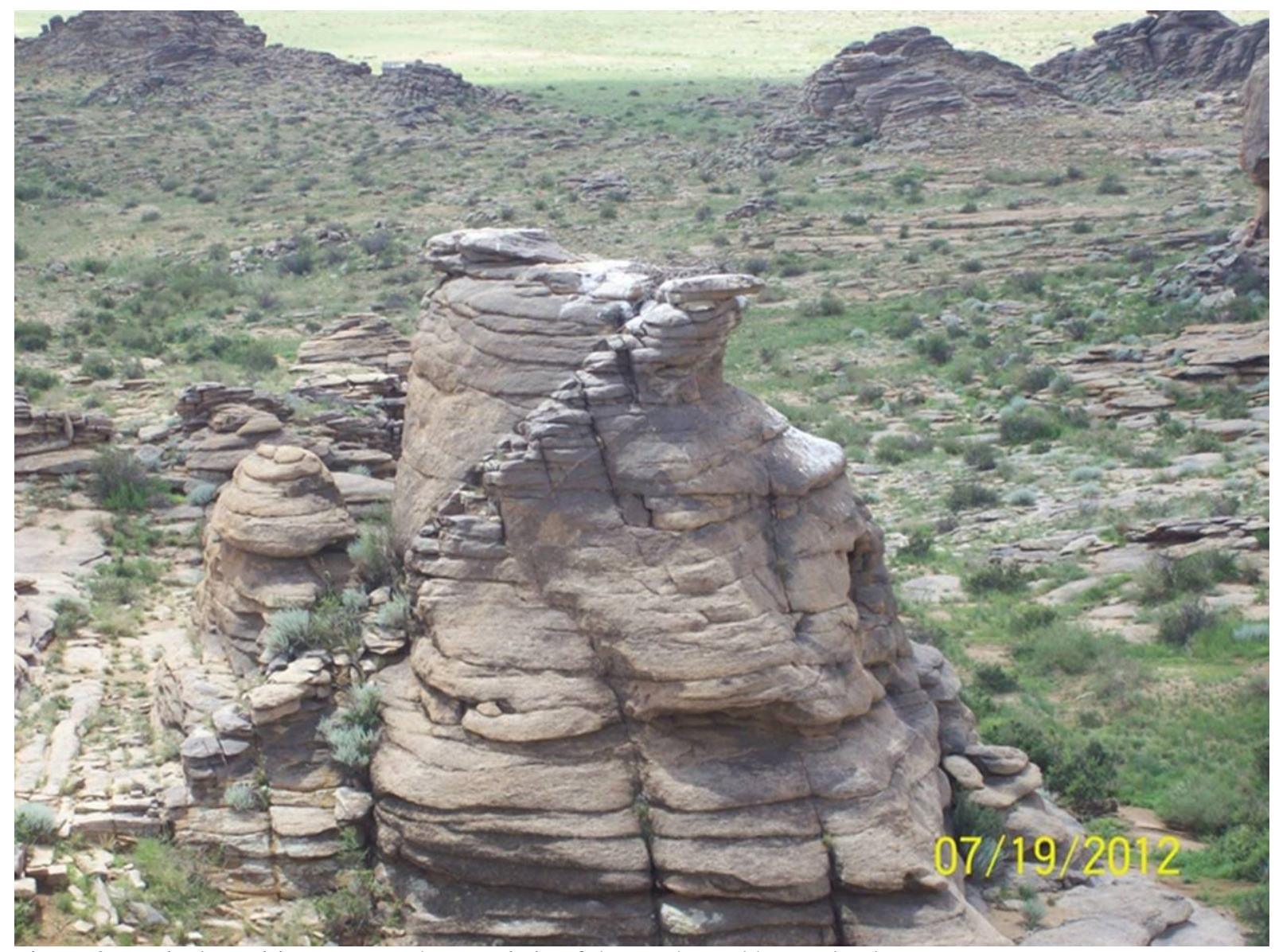

Figure 3. Typical granitic outcrops characteristic of the northern Ikh Nart landscape.

Geologically, the northern portion of Ikh Nart consists of granitic rocks. Southward, about halfway along its length, the Reserve geological landscape changes to young igneous outcrops of basalts (Majigsuren \& Treworgy 2011). Within the southern portion of Ikh Nart, we have identified in several places cryptocrystalline cobbles in drainages and nodules within desert pavements on alluvial fans.

Ikh Nart lies at very high altitude, as does the whole of Mongolia; the research camp is at $1,170 \mathrm{~m}$. (3838 ft.) AMSL. Aridity and diurnal temperature variation are notable characteristics of the environment. Several perennial springs are present, but local herder families rely on wells for their own and their herds' water needs. Trees are present only along drainages and are mostly Siberian elm (Ulnus pumila) and willows (Salix ledebourina). Winters are harsh and long, lasting from October through early May, with December through February, the coldest months; due to the aridity, snow accumulation is low. Spring rains and some snow melt provide the moisture for stipa and grasses (e.g., Allium spp.), shrubs (Artemisa spp.) and wildflowers such as irises (Iris tenuifolia), lilies (Lilium pumilum), asters (Heteropappus hispidus), and many more. Spring brings especially severe wind storms, 
although these do occur throughout the year. Summer, between the end of May and September, brings thunderstorms, and hot weather.

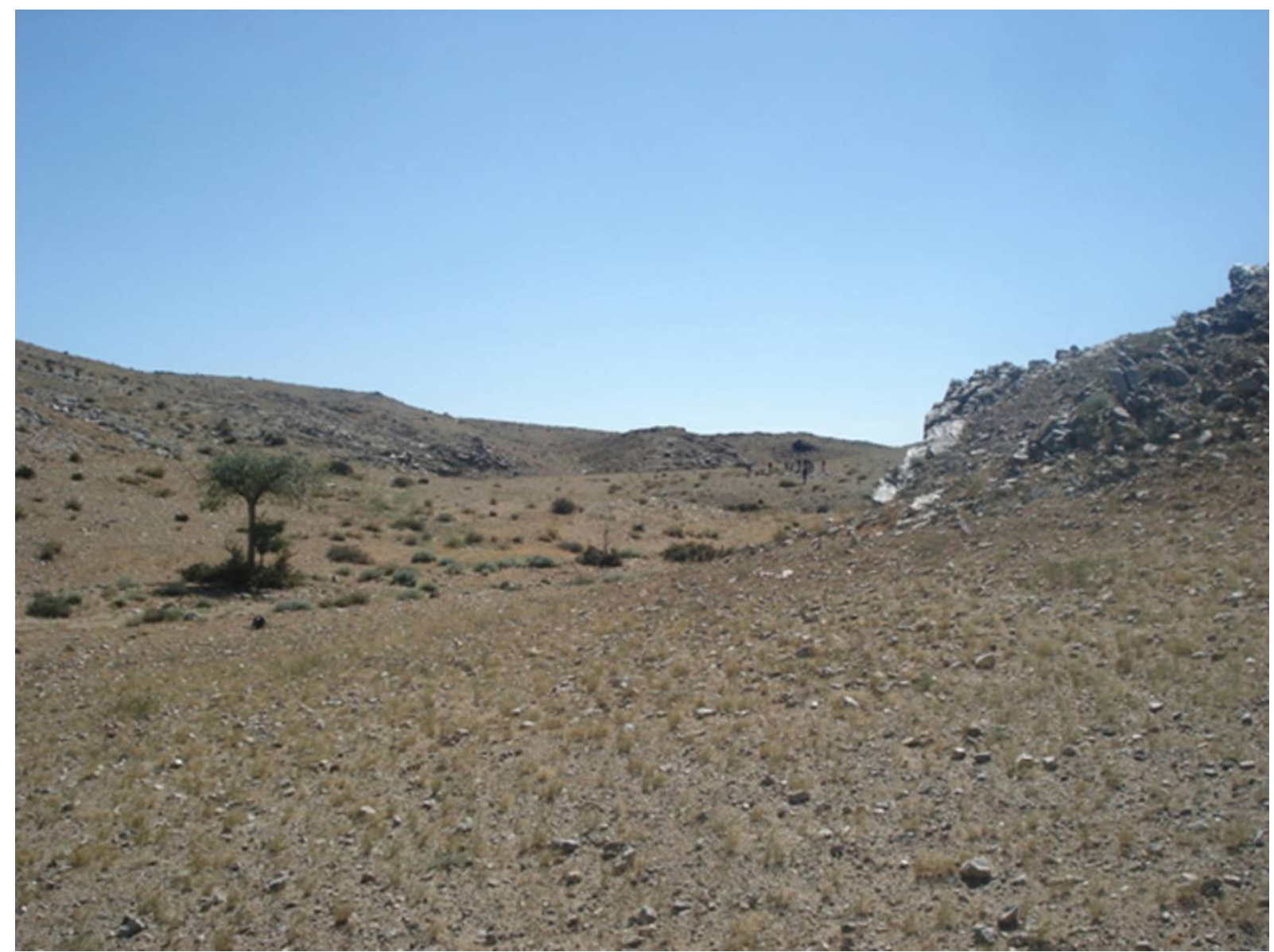

Figure 4. Typical Ikh Nart landscape with small trees along the course of an ephemeral drainage.

Local larger fauna include the protected Argali sheep (Ovis ammon), ibex (Capra ibex sibirica), and two types of gazelles (Procapra gutturosa; Gazella subgutturrosa). Smaller mammals include two types of hedgehogs (long-eared and Darian), pica, gerbil, mice, hamsters, hares, voles, and bats. Ikh Nart is known for its resident raptor populations, including the world's largest species of vulture (Aegypius monachus), eagles (Aquilia spp.), and falcons (Falco spp.); other common raptor species are kestrels, kites, and owls. A huge variety of other bird species also have been identified in Ikh Nart. Common reptiles are the lizards: the toad-headed Agama (Phrynocephalus versicolor) and racerunners (Eremias spp.) and two snakes: the Central Asian viper (Gloydius halys) and a small constrictor (Elaphedion). Many types of insects are also present (see Reading et al. 2011).

\subsection{The "Neolithic" sites}

The "Neolithic" sites that we have identified, to date, usually occur on terraces of major drainages within Ikh Nart. The sites include stone features of unknown function; flaked-stone tools such as the characteristic microblade cores, microblades, unifacial scrapers, projectile points, and bifaces (likely used as axes or adzes), as well as other types of cores, preforms, and debitage; ceramic shards; and ground stone. We note that while the term Neolithic is used here, others have used the terms Epipalaeolithic and Mesolithic for the same types of assemblages (see Wright 2006:23-27; Janz et al. 2009; Wright \& Janz 2012). The same locations have been used through several chronological periods, as we also find Bronze Age, 
Iron Age, and more recent artefacts and features on the surface. In naturally exposed sections along the drainages where the "Neolithic" sites occur, are dark strata characteristic of organically derived sediments of past eras with more moisture. Sediment studies are underway at the Environmental Archaeology Laboratory, The University of Texas, Austin. A single radiocarbon date obtained from a geoarchaeological section associated with one site with a characteristic "Neolithic" assemblage (Ikh-28) has a 3,918 \pm 25 BP conventional radiocarbon age (Rafter $\mathrm{R}$ 40666/2). Calibrated age (at 2 sigma) is 2,473 BCE to 2,335 BCE $(4,422$ BP to 4,284 BP $)$.

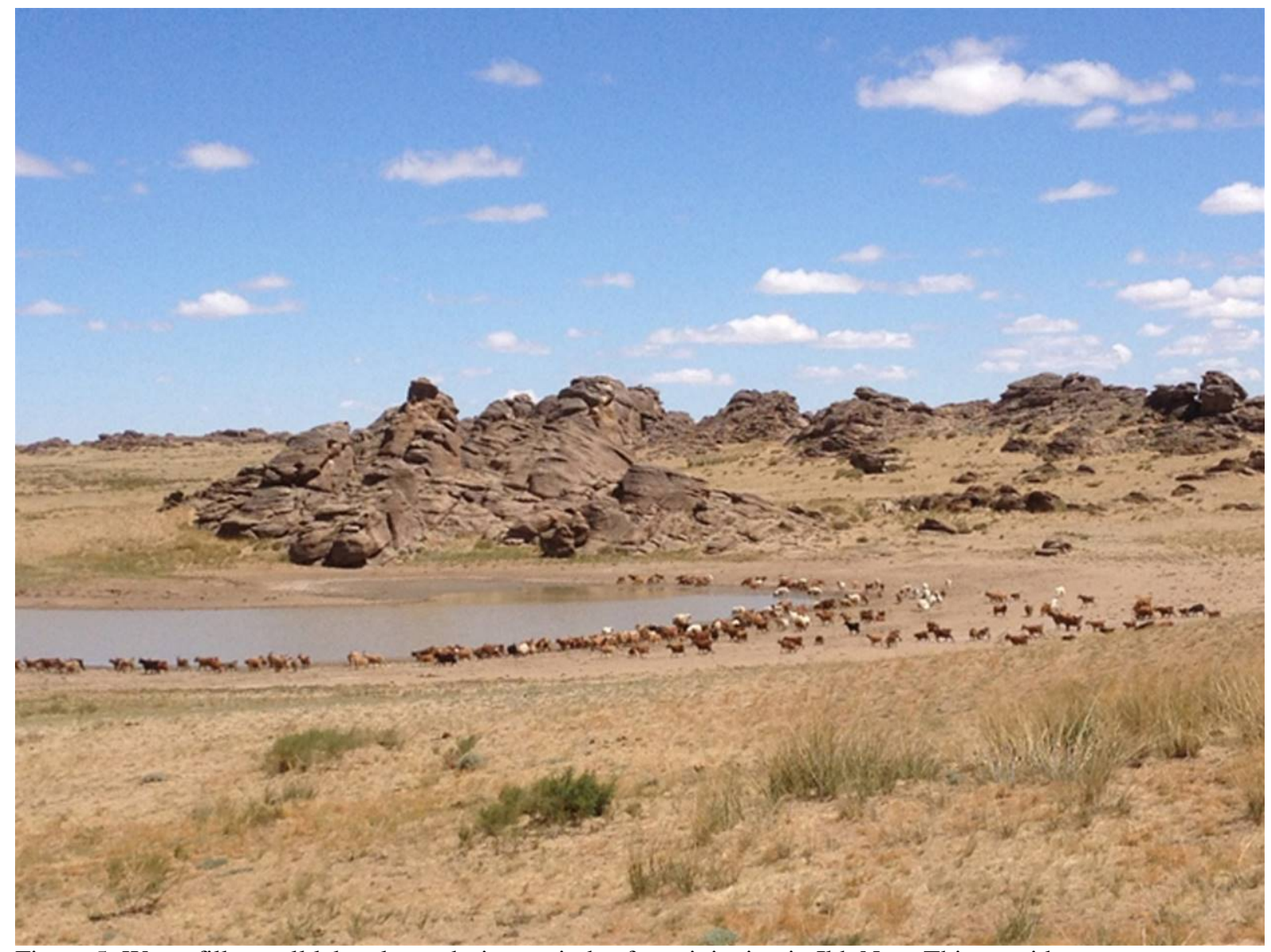

Figure 5. Water fills small lake playas during periods of precipitation in Ikh Nart. This provides temporary water source for mixed goat and sheep herds.

\section{The milling tools}

Here, we describe a number of ground stone artefacts collected from the surfaces of four sites that exhibit characteristic "Neolithic" assemblages: Burgasny Enger (Willow Grove Slope [Ikh-28]), Ulaan Khad (Red Rock [Ikh-78]), Ikh 2, and Ikh-45, (Table 1) as well as the preliminary results of starch grain and phytolith analyses on seven selected artefacts from Ikh78, Ulaan Khad (Table 2).

The vast majority of the milling stones we have observed and collected at Ikh Nart are composed of feldspathic sandstone, sometimes known as greywacke - a few milling stones are of basaltic material; historic-period rotary millstones that we found during survey are of granitic material and vesicular basalt. Geological mapping of Ikh Nart in the area where we are working is not definitive; the mapped geology, along with our field observations seems to indicate that sandstones are not available in the immediate area. 
This infers that sandstone for milling tools was imported, either in raw material or finished form, or carried about. Of the 22 milling stones listed in Table 1, 19 are of sandstones, the majority of which appear to be macroscopically identical sandstone while a few are macroscopically sandstones of more variable textures, two are of basaltic stone, and one is of unidentified stone. Of the 19 sandstone tools, nine have been identified as milling platforms, five as handstones, and one as a pestle. The functional determination of the others has not been made either because they are not readily available for use-wear study or because the morphological similarities between handstones and milling platforms are too great to determine function from small-sized fragments. In Table 1, these are identified as milling stones without further utilitarian determinations.

\subsection{The Ikh Nart "Neolithic" milling tools described}

The typical milling platform is made of sandstone, used unifacially (although a number indicate minimal use on opposing surface), rectangular or sub-rectangular in outline, and shaped and worn about the margins. The milling tools are, on the average, $2.1 \mathrm{~cm}$ thick. Most are relatively small, between $13 \mathrm{~cm}$ and $11 \mathrm{~cm}$ in largest dimension and between $6 \mathrm{~cm}$ and 10 $\mathrm{cm}$ in width (Figures 6 and 7). During the 2015 field season, two additional complete handstones and a large, nearly complete milling platform (reconstructed from five fragments) were recovered from Burgasny Enger. The milling platform measures $30 \mathrm{~cm}$ in length, $21 \mathrm{~cm}$ in width, and ranges between 2 and $1 \mathrm{~cm}$ in thickness; it is worn thin at one end (Figure 8).

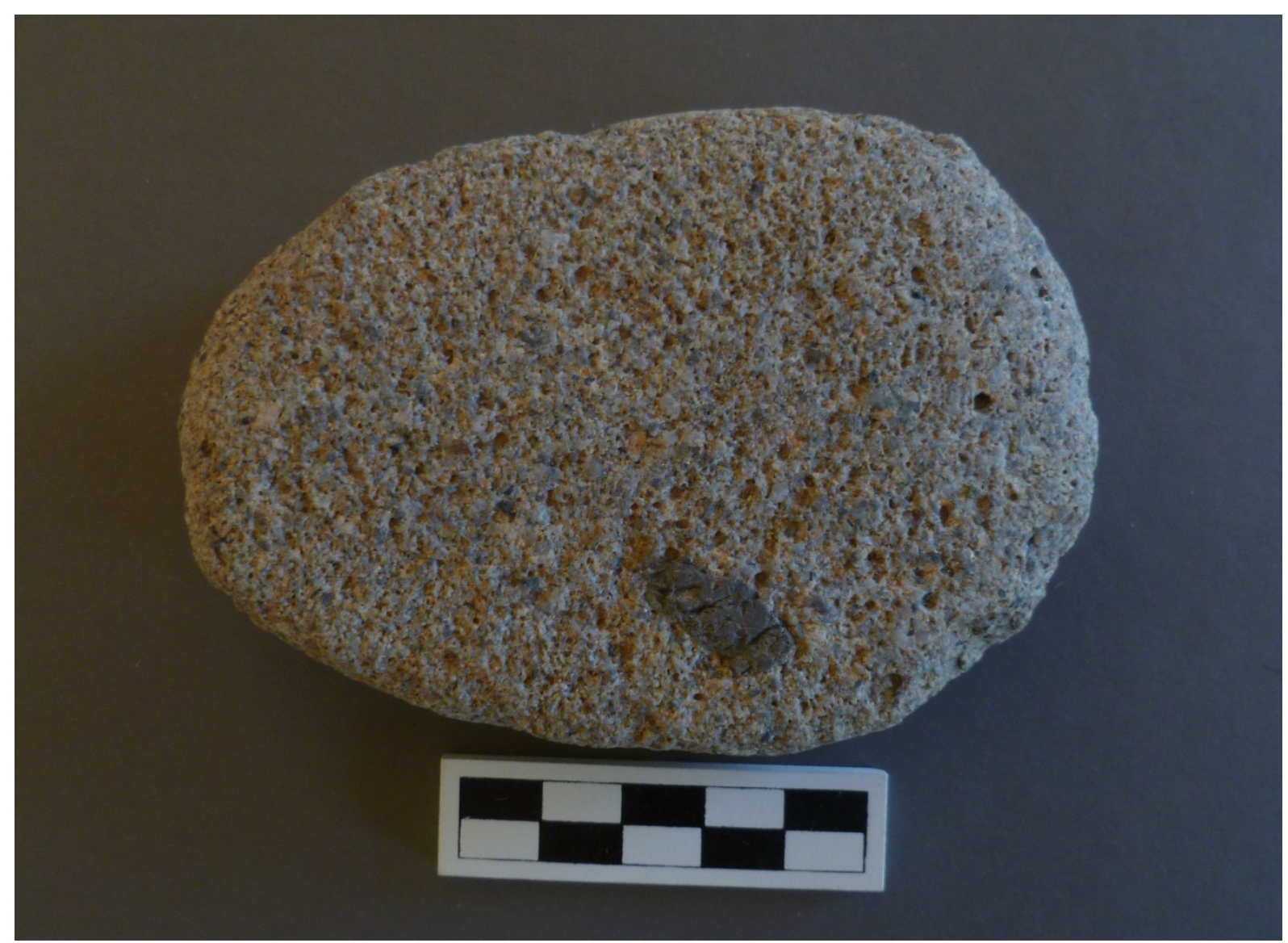

Figure 6. Typical sandstone hand stone from milling tool) from Burgasny Enger (Ikh-28). Plan view of working surface. 
Table 1. Attributes of 22 milling tools from four sites in Ikh Nart Nature Reserve, Dornogovi Aimag, Mongolia. Abbreviations: MP - milling platform; HS - handstone; BF bifacial; UF - unifacial; SS - sandstone; VCSS - very coarse-grained sandstone; frag - fragment

\begin{tabular}{|c|c|c|c|c|c|c|c|c|}
\hline Site No. & $\begin{array}{l}\text { Artefact } \\
\text { No. }\end{array}$ & Tool type & Length (cm) & $\begin{array}{l}\text { Width } \\
\text { (cm) }\end{array}$ & $\begin{array}{l}\text { Thickness } \\
\text { (cm) }\end{array}$ & Use wear & Material & Other information \\
\hline Ikh-2 & 153 & MP & & & & $\mathrm{BF}$ & SS & $\begin{array}{l}\text { Thinner at one end; Nearly complete; Worn } \\
\text { margins }\end{array}$ \\
\hline Ikh-2 & 155 & MP - complete & & & & UF & SS & Thinner at one end; Worn margins; Shaped \\
\hline Ikh-2 & 150 & MP - corner frag & & & & $\mathrm{BF}$ & SS & $\begin{array}{l}\text { Corner of much larger tool; Extreme wear } \\
\text { one side; Partial wear other side; One end } \\
\text { much thinner }\end{array}$ \\
\hline Ikh-2 & 156 & MP (probable) & & & & UF & SS & $\begin{array}{l}\text { "Spoon" shaped; Shaped and polished on } \\
\text { ventral by wear; No use-wear on dorsal }\end{array}$ \\
\hline Ikh-2 & 152 & Pestle -frag & & & & & SS & $\begin{array}{l}\text { Shaped, high polish, end used as hammer } \\
\text { (flakes removed); Oval in cross-section; } \\
\text { Could also have been used as handstone } \\
\text { on milling platform }\end{array}$ \\
\hline Ikh-2 & $154 \mathrm{~A}$ & HS & & & & UF & SS & $\begin{array}{l}\text { Sub-rectangular; Uniform thickness; } \\
\text { Moderate use }\end{array}$ \\
\hline Ikh-2 & 154B & HS & & & & UF & SS & Moderate use; Uniform thickness \\
\hline Ikh-45 & 56 & MP - corner frag & & 5.5 & & UF (probable) & SS & Corner fragment ; shaped \\
\hline $\begin{array}{l}\text { Ikh-28 } \\
\text { Locus A }\end{array}$ & 3 & MP - corner frag & & & 2.8 & $\mathrm{BF}$ & SS & Use-wear in centre of the tool \\
\hline $\begin{array}{l}\text { Ikh-28 } \\
\text { Locus A }\end{array}$ & 4 & MP - corner frag & & & 2.7 & UF & VCSS & $\begin{array}{l}\text { Moderate wear; Margins are well-finished } \\
\text { (shaped); Possibly part of \#5 }\end{array}$ \\
\hline $\begin{array}{l}\text { Ikh-28 } \\
\text { Locus A }\end{array}$ & 5 & MP - corner frag & & & $3.1-2.5$ & UF & VCSS & $\begin{array}{l}\text { Worn in centre of tool, Carefully shaped; } \\
\text { Possibly part of \#4 }\end{array}$ \\
\hline $\begin{array}{l}\text { Ikh-28 } \\
\text { Locus A }\end{array}$ & 6 & $\begin{array}{c}\text { Almost } \\
\text { complete MP }\end{array}$ & & & $\begin{array}{l}2.87-2.4 \text { at } \\
\text { margins; } \\
1.4-1.4 \mathrm{~cm} \\
\text { at centre }\end{array}$ & UF & $\begin{array}{l}\text { VCSS (almost like } \\
\text { silica-cemented in } \\
\text { reticular pattern) }\end{array}$ & $\begin{array}{l}\text { Finely shaped rectangular. Wear pattern } \\
\text { well-defined; oval area in centre with } \\
\text { polish; Appears to have been used with } \\
\text { circular motion. }\end{array}$ \\
\hline $\begin{array}{l}\text { Ikh-28 } \\
\text { Locus A }\end{array}$ & 7 & MP -frag & & & $2.6-1.2$ & $\mathrm{BF}$ & $\begin{array}{l}\text { Unknown tabular } \\
\text { material, not SS }\end{array}$ & $\begin{array}{l}\text { Not shaped; Absolutely flat on both sides; } \\
\text { one side used over complete surface; other } \\
\text { side used in central area }\end{array}$ \\
\hline $\begin{array}{l}\text { Ikh-28 } \\
\text { Locus A }\end{array}$ & 8 & MP & & & 5.1 & $\mathrm{BF}$ & $\begin{array}{l}\text { Very thick slab of } \\
\text { volcanic or meta- } \\
\text { volcanic }\end{array}$ & Extremely flat; Use wear both faces \\
\hline
\end{tabular}




\begin{tabular}{|c|c|c|c|c|c|c|c|c|}
\hline Site No. & $\begin{array}{l}\text { Artefact } \\
\text { No. }\end{array}$ & Tool type & Length $(\mathrm{cm})$ & $\begin{array}{l}\text { Width } \\
\text { (cm) }\end{array}$ & $\begin{array}{l}\text { Thickness } \\
\text { (cm) }\end{array}$ & Use wear & Material & Other information \\
\hline $\begin{array}{l}\text { Ikh-28 } \\
\text { Locus A }\end{array}$ & 9 & $\begin{array}{l}\text { HS frag (2 of } 3 \\
\text { frags) }\end{array}$ & $\begin{array}{l}\text { (possibly 16.0) } \\
2 \text { fragments, } \\
\text { together } \\
\text { measure } 10.5\end{array}$ & & $\begin{array}{l}5.2 \text { in one } \\
\text { direction; } \\
3.2 \text { in the } \\
\text { other }\end{array}$ & $\begin{array}{l}\text { Used on all faces; } \\
\text { Bevelled areas } \\
\text { along length of } \\
\text { the tool. }\end{array}$ & $\begin{array}{l}\text { Fine-grained grey } \\
\text { SS }\end{array}$ & $\begin{array}{l}\text { The two portions of this tool were found } 30 \\
\text { meters apart, one uphill from the other. } \\
\text { Oval in cross-section; Likely used with } \\
\text { back-and-forth motion }\end{array}$ \\
\hline Ikh-78* & 1 & $\begin{array}{l}\text { MP -almost } \\
\text { complete; } \\
\text { Missing corner }\end{array}$ & 11.6 & 9.7 & 1.9 & UF & SS & $\begin{array}{l}\text { Working surface facing downward; Non- } \\
\text { grinding surface looks unused; Uncertain } \\
\text { whether platform or handstone, but likely } \\
\text { the latter as margins on working surface } \\
\text { are slightly rounded }\end{array}$ \\
\hline Ikh-78* ts & 2 & $\begin{array}{l}\text { MP HS frag } \\
\text { (probable) } \\
\text { (small, centre } \\
\text { portion) }\end{array}$ & (6.5) & 6.5 & 2.4 & $\begin{array}{l}\text { BF but one side } \\
\text { more heavily } \\
\text { used }\end{array}$ & SS & $\begin{array}{l}\text { Found partly buried; Collected soil sample; } \\
\text { Shaped. Likely part of a long handstone } \\
\text { used with back and forth motion; One } \\
\text { margin on less heavily used side is bevelled }\end{array}$ \\
\hline Ikh-78* & 3 & $\begin{array}{c}\text { MP frag } \\
\text { (possibly 1/2 or } \\
1 / 4 \text { of large hand } \\
\text { stone) }\end{array}$ & (9.0) & (9.3) & $2.9-2.1$ & $\mathrm{BF}$ & SS & $\begin{array}{l}\text { Working surface facing downward; Shaped; } \\
\text { Looks like an originally semi-circular } \\
\text { shaped OR one margin used after breaking } \\
\text { off. Margin is heavily worn and polished; } \\
\text { Wear striations from obvious back-and- } \\
\text { forth motion }\end{array}$ \\
\hline Ikh-78* ts & 4 & MP frag & (6.0) & (4.0) & 1.9 & UF & SS & $\begin{array}{l}\text { Working surface was exposed; Shaped; } \\
\text { One margin remains on fragment }\end{array}$ \\
\hline Ikh-78* ts & 5 & $\begin{array}{l}\text { MP frag (very } \\
\text { small) }\end{array}$ & (5.5) & (5.0) & (1.9) & UF (probable) & SS & $\begin{array}{l}\text { Very weathered and broken; One segment } \\
\text { of original margin remains; May be } \\
\text { battered }\end{array}$ \\
\hline Ikh-78* & 6 & $\begin{array}{l}\text { Small HS - } \\
\text { complete }\end{array}$ & 13.1 & $6.2-4.5$ & $2.5-1.0$ & UF & SS & $\begin{array}{l}\text { Working surface facing downward; Shaped; } \\
\text { one short end on working side is almost } \\
\text { bevelled }\end{array}$ \\
\hline Ikh-78* & 7 & $\begin{array}{l}\text { Large frag of } \\
\text { MP; angular } \\
\text { naturally } \\
\text { shaped basalt } \\
\text { block }\end{array}$ & 21.0 & 11.5 & 5.5 & UF & Basaltic & $\begin{array}{l}\text { Major working side facing downward; } \\
\text { extending from buried context; Soil sample }\end{array}$ \\
\hline
\end{tabular}


Table 2. Starches recovered from milling tools.

\begin{tabular}{|c|c|c|c|c|}
\hline $\begin{array}{l}\text { Artefact No. } \\
\text { Sample No. }\end{array}$ & Starches recovered & Tool Type & Use & Material \\
\hline $\begin{array}{c}\text { Ikh-78-1 } \\
15-30 \\
15-31 \\
15-32 \\
15-33 \\
15-34\end{array}$ & $\begin{array}{l}1 \text { starch on one point } \\
\text { sample }\end{array}$ & $\begin{array}{l}\text { milling stone } \\
\text { almost complete; } \\
\text { (missing corner) }\end{array}$ & unifacial & sandstone \\
\hline $\begin{array}{c}\text { Ikh-78-2 } \\
15-30 \\
15-31 \\
15-32 \\
15-33 \\
15-34\end{array}$ & $\begin{array}{l}1 \text { starch on one point } \\
\text { sample }\end{array}$ & $\begin{array}{l}\text { milling stone } \\
\text { (possibly } \\
\text { handstone) small } \\
\text { fragment centre } \\
\text { portion }\end{array}$ & $\begin{array}{l}\text { bifacial but } \\
\text { one side } \\
\text { more } \\
\text { heavily } \\
\text { used }\end{array}$ & sandstone \\
\hline $\begin{array}{c}\text { Ikh-78-3* } \\
15-36 \\
15-37 \\
15-38 \\
15-39 \\
15-40\end{array}$ & none & $\begin{array}{l}\text { milling stone } \\
\text { fragment }(\sim 1 / 2 \text { or } \\
1 / 4 \text { of large milling } \\
\text { stone }\end{array}$ & bifacial & sandstone \\
\hline $\begin{array}{c}\text { Ikh-78-4* } \\
15-41 \\
15-42 \\
15-43 \\
15-44 \\
15-45\end{array}$ & $\begin{array}{l}2 \text { starches in sonicated } \\
\text { sample }\end{array}$ & $\begin{array}{l}\text { milling stone } \\
\text { fragment }\end{array}$ & unifacial & sandstone \\
\hline $\begin{array}{l}\text { Ikh-78-5* } \\
15-25 \\
15-26 \\
15-27 \\
15-28\end{array}$ & $\begin{array}{l}1 \text { cooked starch on one } \\
\text { point sample; } \\
4 \text { starches in sonicated } \\
\text { sample }\end{array}$ & $\begin{array}{l}\text { milling stone } \\
\text { fragment (very } \\
\text { small) }\end{array}$ & unifacial & sandstone \\
\hline $\begin{array}{l}\text { Ikh-78-6* } \\
\text { Not applicable }\end{array}$ & $\begin{array}{l}2 \text { starches from one } \\
\text { point sample; } 1 \text { grinding- } \\
\text { damaged starch from } 1 \\
\text { point sample; } 1 \text { starch } \\
\text { from sonicated sample }\end{array}$ & $\begin{array}{l}\text { small handstone } \\
\text { (complete) }\end{array}$ & unifacial & sandstone \\
\hline $\begin{array}{l}\text { Ikh-78-7* } \\
\text { Not applicable }\end{array}$ & $\begin{array}{l}2 \text { starches from one } \\
\text { point sample }\end{array}$ & $\begin{array}{l}\text { milling stone } \\
\text { (large fragment } \\
\text { of milling } \\
\text { platform) }\end{array}$ & unifacial & $\begin{array}{l}\text { unshaped } \\
\text { basalt block }\end{array}$ \\
\hline
\end{tabular}




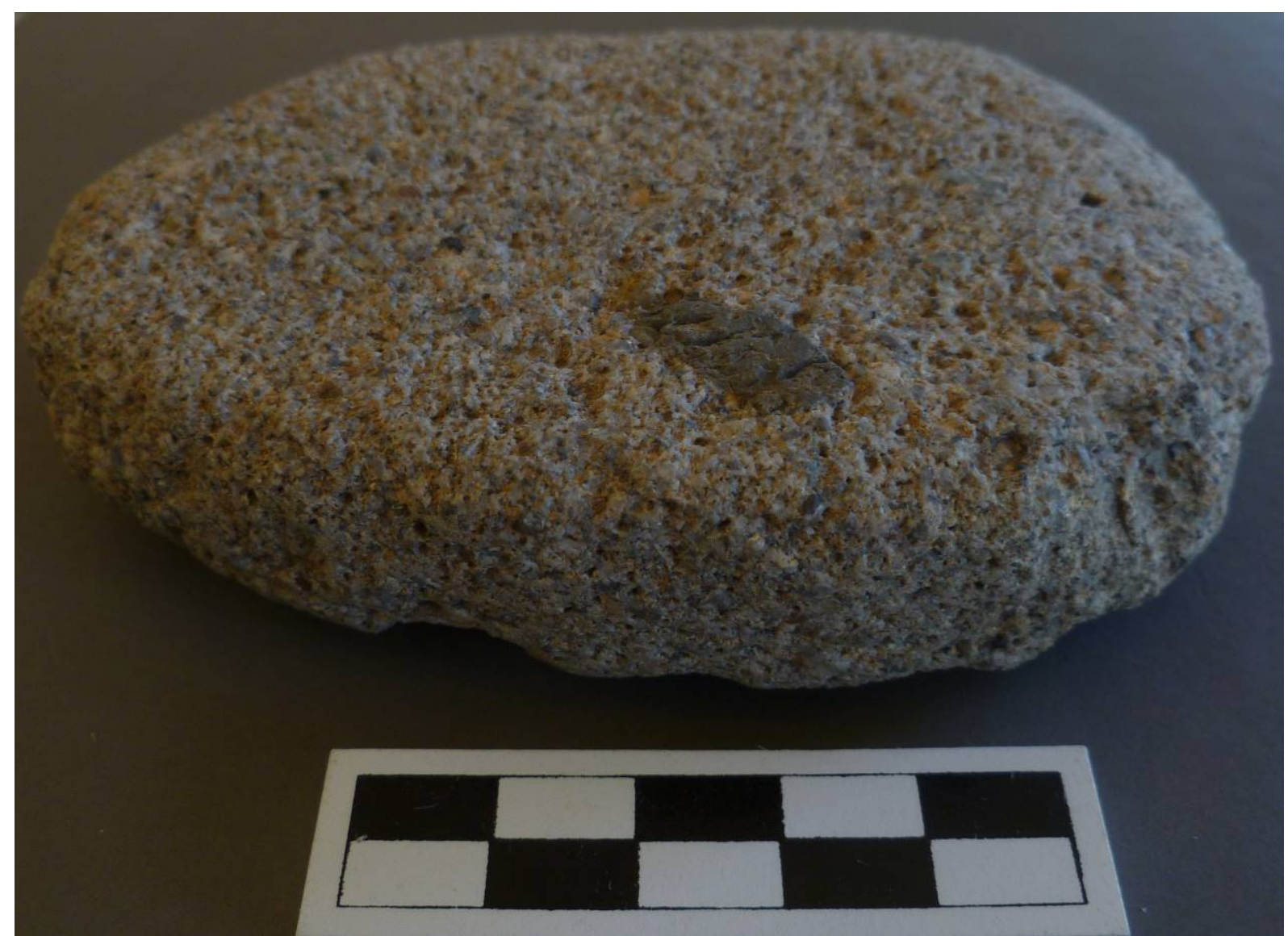

Figure 7. Typical hand stone from Burgasny Enger (Ikh-28). Profile view of artefact shown in Figure 6.

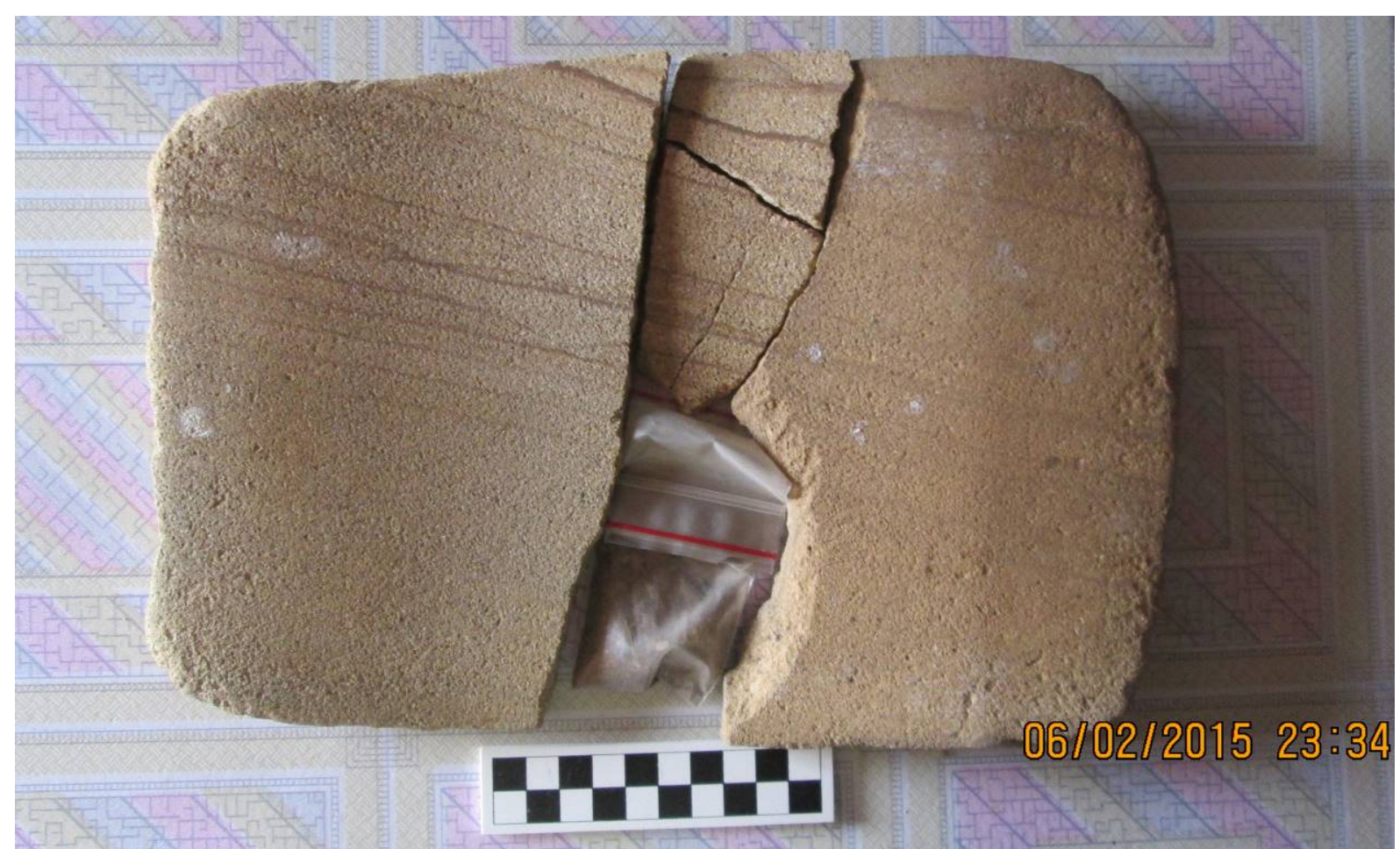

Figure 8. Nearly complete well-used milling platform that was collected in fragments in 2015 from Burgasny Enger (Ikh-28). Plastic bag contains associated sediment sample. 
When only fragments of the milling tools are found, it is often difficult to distinguish, in the field, milling platforms from handstones; the shaping techniques are similar; both types of tools are relatively thin and wear patterns on both tools indicate reciprocal motions during use. More detailed study is required to fully understand use-wear and to more definitively distinguish handstones from milling platforms. Preliminary observations indicate that the used surfaces of both milling platforms and handstones are flat or almost flat and that the handstones seem to have been used with two hands and in a reciprocal motion along the greater length of the milling platforms. The milling platform from Burgasny Enger (Ikh-28) shown in Figure 8 has a flat, raised platform-like portion at one end; we have not observed this on other milling platforms. Basaltic milling platforms are thicker than the sandstone tools - about $5 \mathrm{~cm}$ thick, on an average. The variable thicknesses and edge modifications of this sample of milling tools, such as on artefacts 3 and 6 at Ulaan Khad and artefacts 5 and 7 at Burgasny Enger, indicate that heavy use accounts for the attrition of portions of the tools. It may be that bevelled edges are indicators of use as handstones. Alternatively, further study of the wear patterns on the tools may indicate multiple uses of the tools.

\subsection{Petrography}

In order to definitively identify the stone from which most of the milling tools are made, thin-section petrographic slides were made from fragments taken from three of the seven milling-tools from Ulaan Khad that had been subject to palaeobotanical recovery (see Table 2, above). The slides were viewed in both direct and cross-polarized light under a petrographic microscope (see Figure 9, for example). All three are described as sandstone wacke (Wacke is sandstone that is poorly sorted. Arkose wacke is poorly sorted sandstone that is composed of at least 25\% feldspar.). Two are very similar; one is slightly different than the other two and is described as arkosic wacke. Preliminary research of the available geological literature suggests that the sources of the sandstones are somewhere to the north of Ikh Nart within the Hangay-Hentey basin.

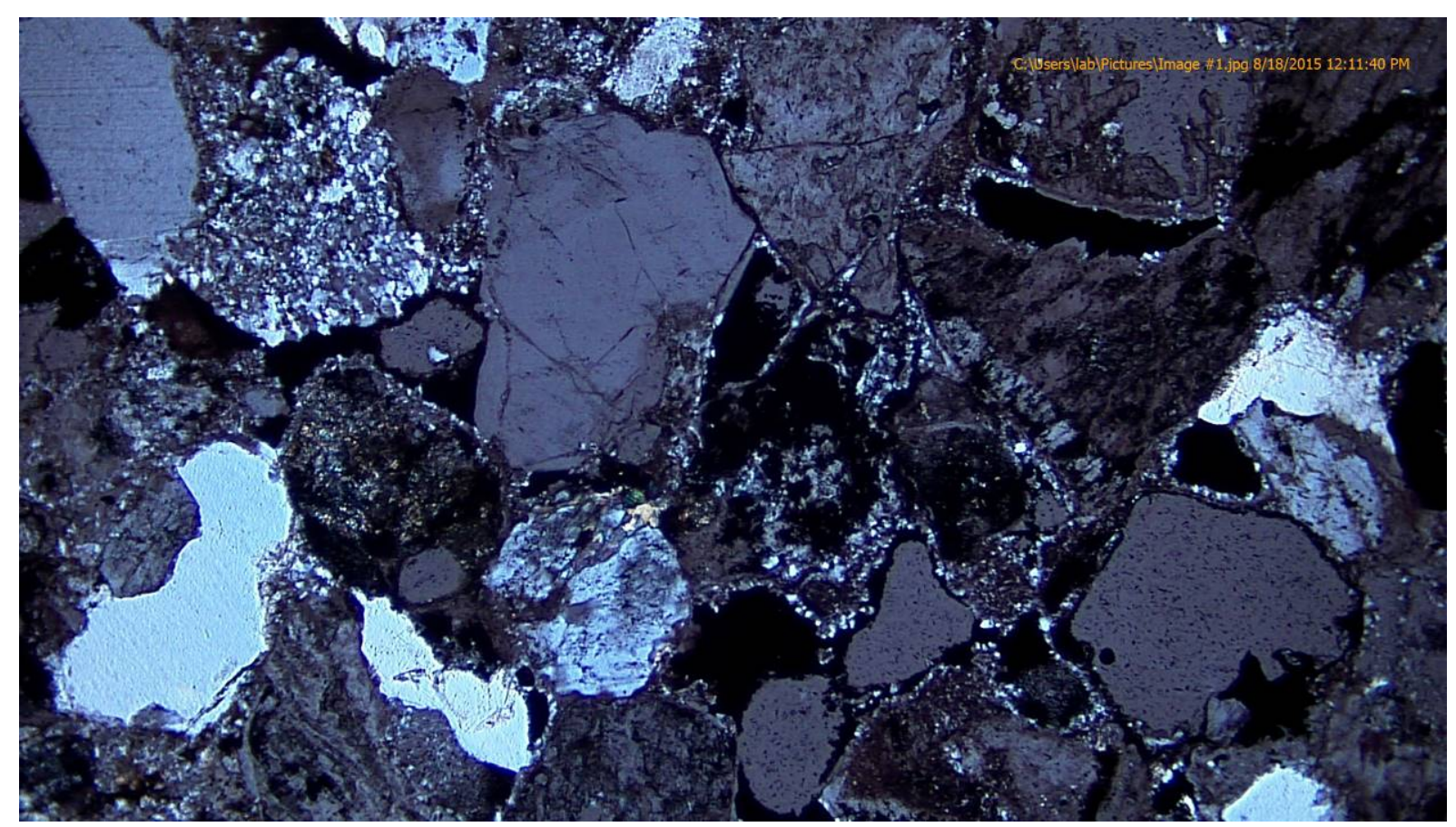

Figure 9. Petrographic image from Artefact 2, UlaanKhad (Ikh-78) in cross-polarized light at 40x magnification. 


\section{Milling tool laboratory studies}

Our research goal of better understanding Mongolian "Neolithic" subsistence and behaviour patterns led us to undertake further analyses of the seven artefacts and associated sediment samples from Ulaan Khad (Ikh-78) collected during the 2014 field season that we were able to import to the USA in 2014. Matching sediment samples are used to rule out naturally occurring palaeobotanical residues in the soils closely associated with each artefact. Both the artefacts and the sediments were imported to the United States with the permission of the Institute of History and Archaeology, Mongolian Academy of Sciences; all artefacts were returned to the collections at that institution in 2015. The following protocol was used (see also Chandler-Ezell \& Pearsall 2003):

1) Samples of dry sediments were removed from the collection bags and weights were taken of the dry sediment sample from the collection bag and set aside.

2) Each artefact was then removed from its collection bag and then the artefact was drybrushed with a clean toothbrush. Sediment from the dry brushing was placed in a $50 \mathrm{~mL}$ test tube. This sample is referred to as a Sediment 1 sample.

3) Two or three point samples were then taken at selected locations over the surface of the artefact (use-surfaces, base, broken unused faces, and others) by washing those points with distilled water using a pipette. Each wash-sample was placed in a labelled $15 \mathrm{~mL}$ test tube.

4) Fresh distilled water was applied to the working surface (or surfaces) of each milling tool and the tool was brushed with a new toothbrush. The resulting solution was then transferred to a $50 \mathrm{~mL}$ test tube. This sample is referred to as a Sediment 2 sample.

5) The milling tool was then transferred to a clean plastic bag. Distilled water was added and the artefact in the bag was sonicated for 5 minutes. The resulting solution was transferred to $50 \mathrm{~mL}$ test tubes. This sample is referred to as a Sediment 3 sample.

6) Samples were then either mounted (if not very dirty) or floated using sodium polytungstate calibrated to a specific gravity of 2.3 ( $3 \mathrm{~mL}$ added to each sample) for 10 minutes at $800 \mathrm{rpm}$. The sample solution was poured into a clean test tube. Distilled water was then added to the samples and centrifuged at $2000 \mathrm{rpm}$ for 5 minutes (to drop the starches to the bottom of the tube). The supernatant was then poured off, leaving starch behind. Samples were then mounted on slides with Entellan.

\subsection{Starch and phytolites results}

In that this was a trial study to determine if plant residues could be recovered, only point samples and sonicated samples (Sediment 3) from each artefact were studied; these were the samples that had the highest potential for recovering residues, based on our previous laboratory experience (Figures 10 to 14). The results from 21 samples indicate that plant residues can be recovered; 15-16 starch grains were recovered as well as a single phytolith: a dendritic long-cell. Although the taxonomic identification for the starch grains and the phytolith are not yet available, observations by Hart, based on the research of Henry et al. (2009), point out cultural activities such as cooking and grinding are reflected by some of the starch grains recovered (Figures 12 and 13).

These results are hopeful in that they indicate that (1) "Neolithic" starch grains can be recovered from Mongolian "Neolithic" milling tools and (2) that cultural alteration of the recovered grains can be identified. Further work will provide botanical identification of the plant type and perhaps the identification of species. Figures 10 to 14 are photographs of slides from the laboratory starch grain studies. 


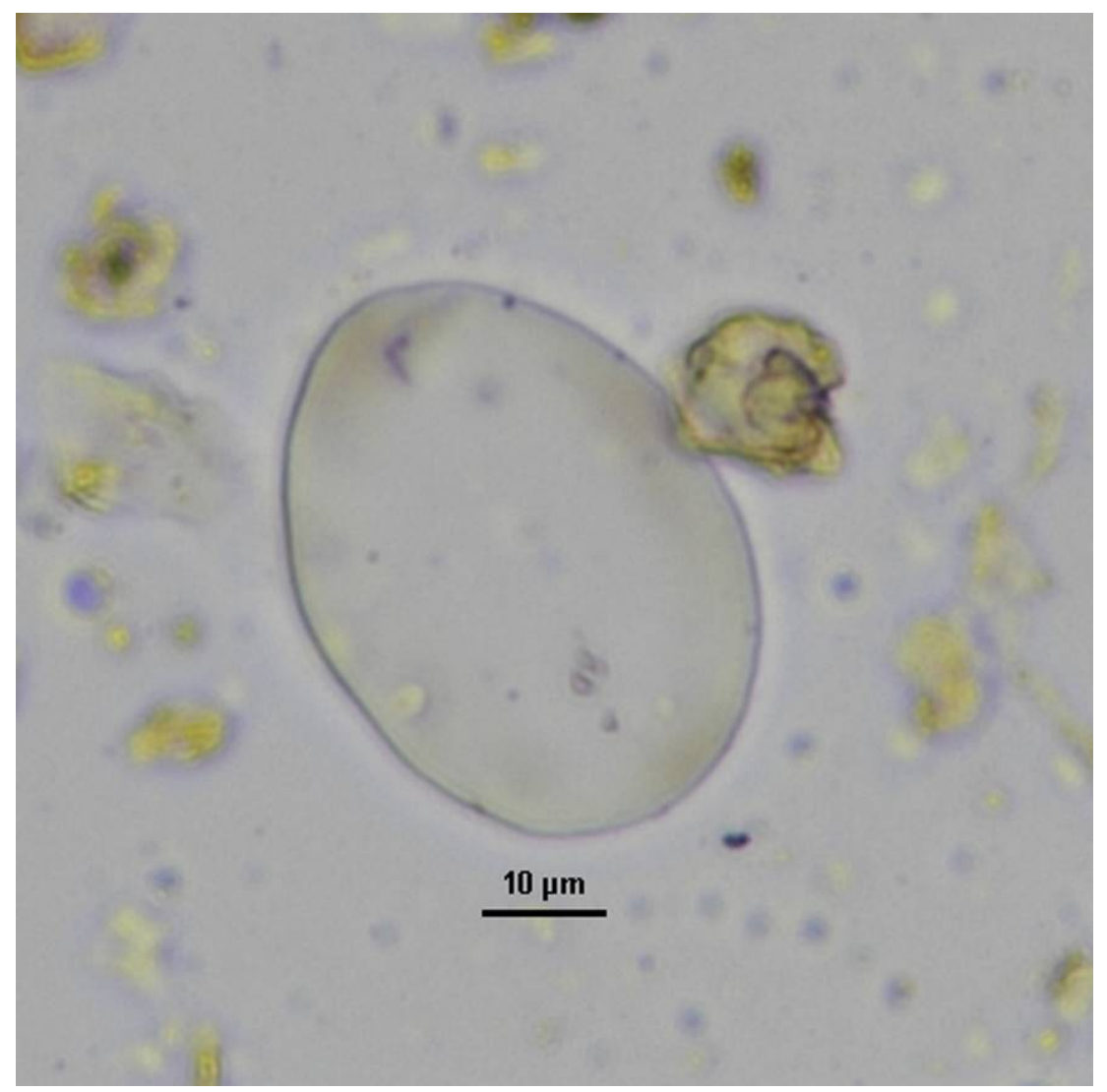

Figure 10. Recovered starch grain in polarized light. Artefact 5, point sample 1, at 400x.

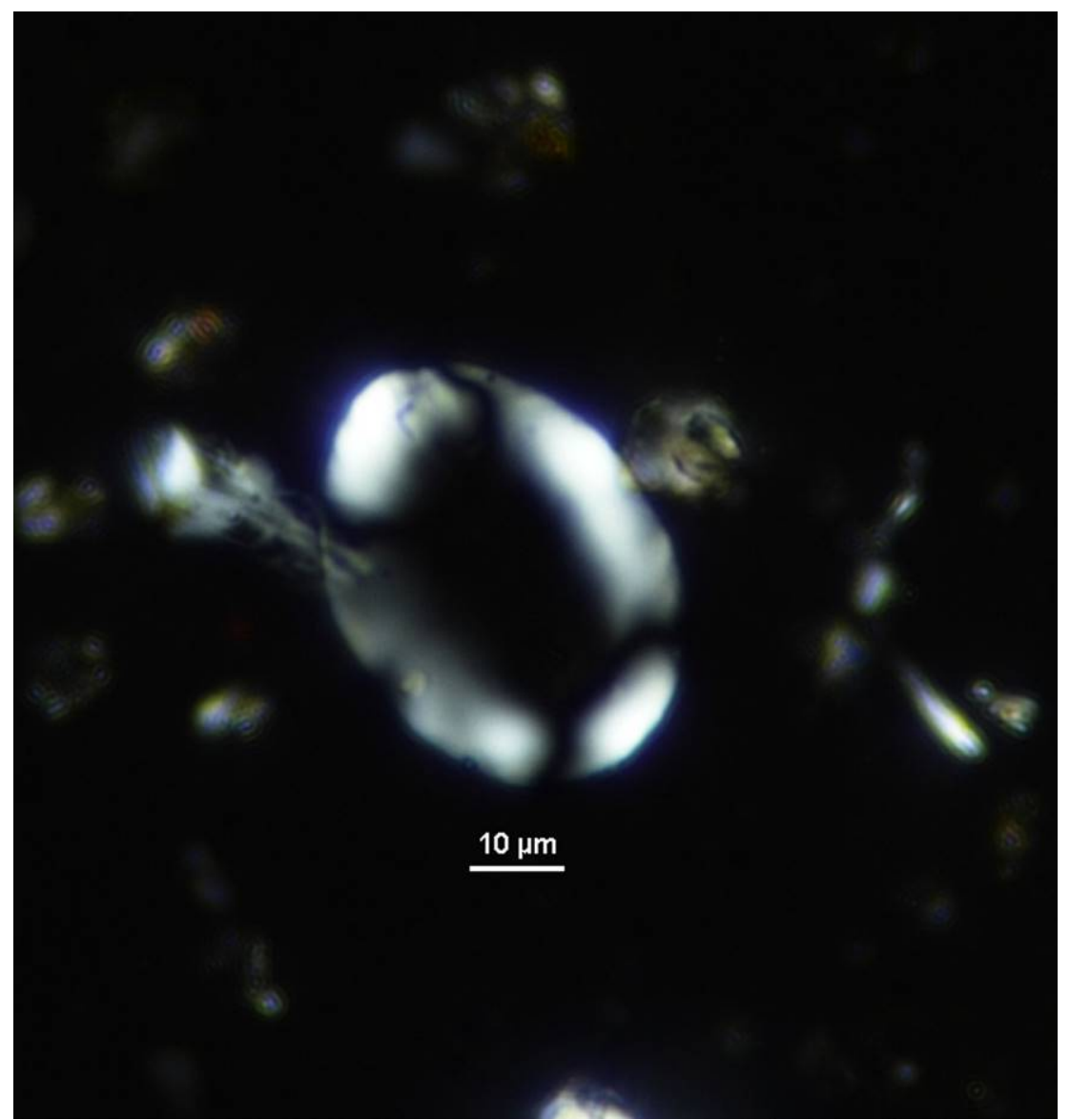

Figure 11. Recovered starch grain in transmitted light. Artefact 5, point sample 1, at 400x. 


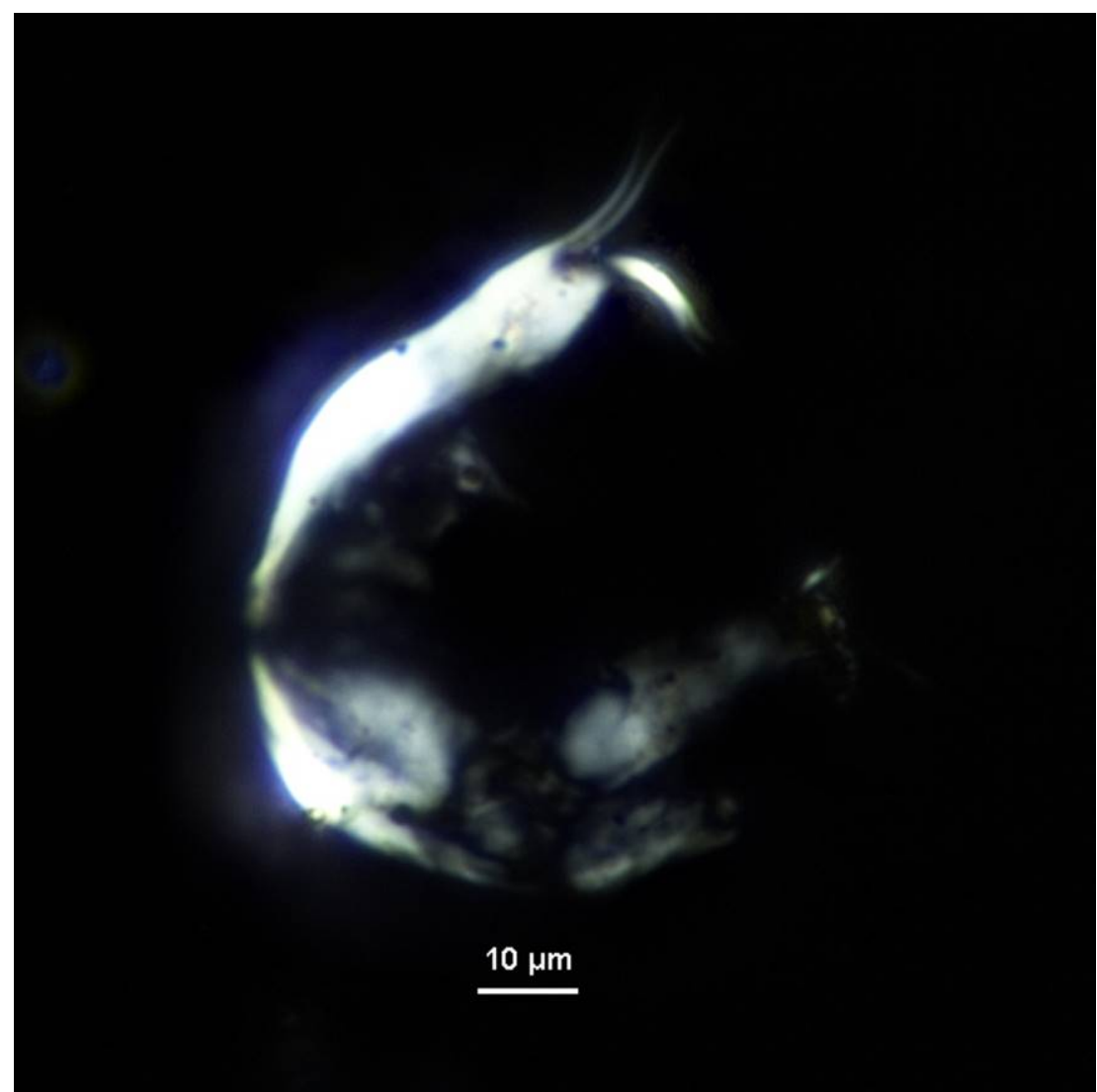

Figure 12. Recovered cooking or arching-damaged starch grain: polarized Artefact 6, point sample 2 at 400x.

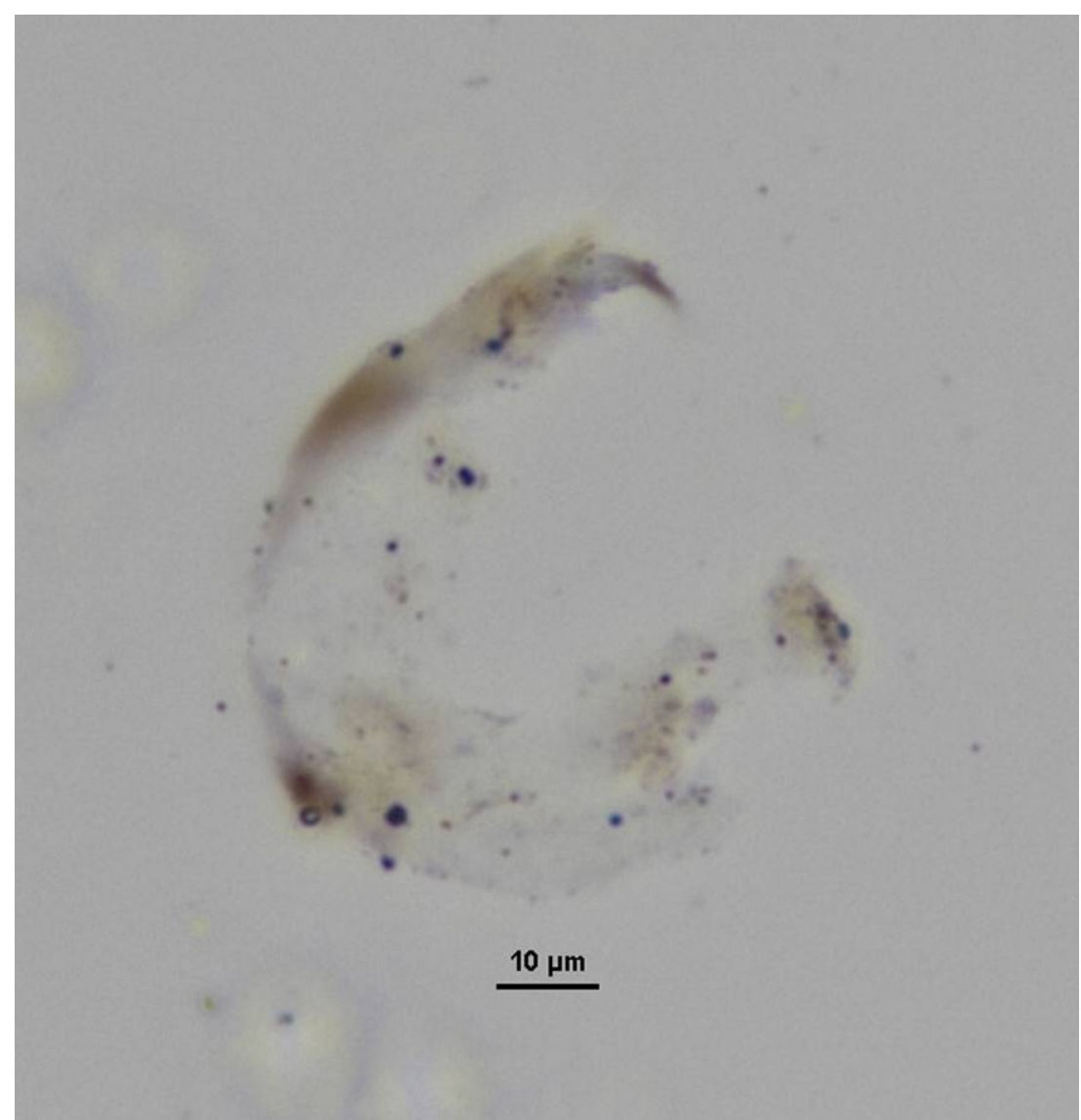

Figure 13. Recovered cooking or parching damaged starch grain: transmitted light. Artefact 6, point sample 2 at 400x. 


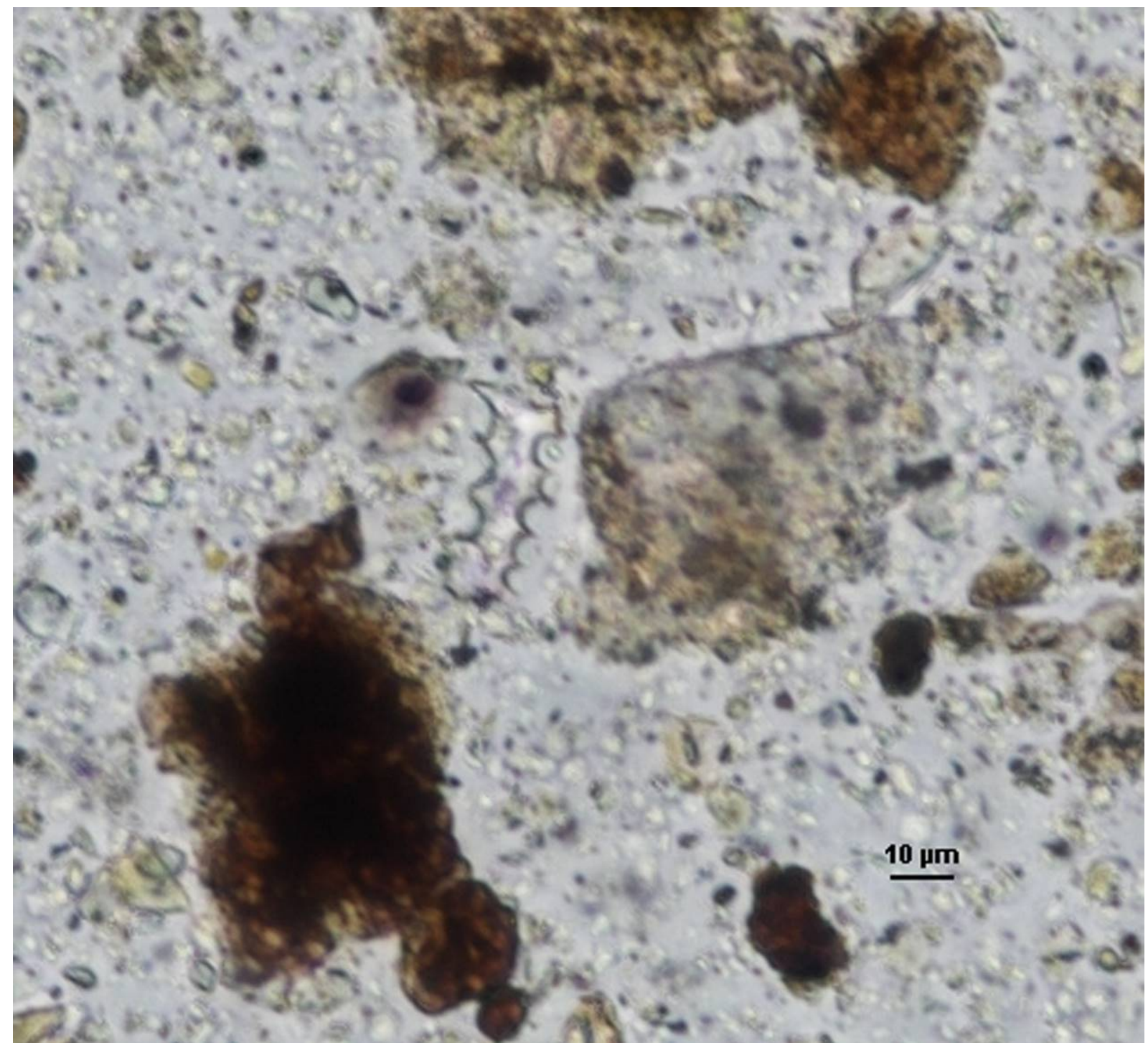

Figure 14. Single dendritic long-cell recovered at 400x.

\section{Discussion of results and direction for future work}

Milling tools hold important keys to better understanding Mongolian "Neolithic" lifeways in the Ikh Nart area, as well as the postulated transition from "Neolithic" to Bronze Age pastoralism. We have shown that it is possible to recover starches from milling tools that have been exposed on site surfaces for thousands of years. Further work is needed, especially paleo-environmental research at the sites that are thought to have characteristic "Neolithic" artefact assemblages and features. Excavations of rock features at these sites and intensive study of milling tools and sediments associated with these features may contribute to a clearer picture of pre-pastoral times in the region. If the pre-Bronze Age peoples of this region of Mongolia were members of sedentary agricultural communities or if they were harvesting abundant wild plants on a regular basis, milling tools would have been an important part of the economy. Milling tools contain the data to determine if plant foods were wild or domesticated how they were processed, and what type of environment prevailed at the time they were used. Those data would go far toward addressing many research questions about this little-understood span of time.

Milling tools hold other information too: where did the characteristic sandstone come from, if it is, indeed, not local? Does non-local material mean that people lived a migratory 
life before pastoralism? Or does it suggest that long-distance trade and travel networks were in place to bring needed (or desired) goods to sedentary groups? What distances were travelled and in what direction to obtain the milling-tool materials? How much labour investment was called for in obtaining material and shaping the tools? Definitive sourcing of milling-tool material and experimental replication studies would provide some of these answers.

The apparent absence of bedrock processing features at Ikh Nart and elsewhere in the Mongolian Gobi-steppe region poses another problematic situation. Bedrock processing features are extremely common in similar desert environments in the American Southwest and in southwestern Asia. In our view, the ready availability of flat-surfaced natural granitic outcrops within Ikh Nart calls into question the reasons why these surfaces were not used as milling platforms as they were in other culture areas. Cultural differences may account for natural outcrops not being used; alternatively, the lack of use of natural outcrops may have functional explanations.

Our observations and the sample of milling tools that we have studied in a preliminary fashion indicate that there is remarkable uniformity in milling-tool material, shape, and size. A majority of the tools we have identified suggest that they were small enough to be readily portable. Yet, uniformity of shape and size (i.e. standardization) in plant-processing tool kits is thought of as associated with more sedentary societies, at least incipient agriculture, and some degree of craft specialization, but as we see here, not necessarily with societal complexity as in settled stratified society (Costin 1991; Schneider 2002).

Milling tools have received very little attention in Mongolian archaeological inquiry. In our preliminary work at Ikh Nart, we suggest that all aspects of ancient lifeways and environmental archaeology can be explored to further our knowledge of the Mongolian past. We have demonstrated that ancient plant residues are present on milling tools, that there are indications that starches were cooked or parched and otherwise processed, and that milling tools were likely imported from some distance. Our future research will increase our sample data and focus on a holistic view of sites within Ikh Nart that have "Neolithic" components: excavation of apparent features, further analyses of sediments and exploration of other paleoenvironmental indicators, additional in-depth study of use-wear and residues on milling tools and flaked-stone tools, experimental replication of milling tools, and distributional analysis of aerial images of site complexes associated with former drainages and wetlands.

\section{Acknowledgements}

We acknowledge the support of the following organizations and individuals: Earthwatch Institute; Denver Zoological Foundation; Anza Borrego Foundation; Institute of History and Archaeology, Mongolian Academy of Sciences; Mongolian Conservation Coalition; Trust for Mutual Understanding; Fulbright Specialist Grant Program; A. Sukbaatar, Director of Ikh Nart Nature Reserve; D. Sarantuya; S. Tuvedorj; L. Janz; J. Wright, P. Hadel; E. Britton, P. Condi. We are especially indebted to the reviewers of this paper for their perceptive questions, comments, and corrections.

\section{References}

Chandler-Ezell, K.C., \& Pearsall, D.M. 2003, “Piggyback” microfossil processing: Joint starch and phytolith sampling from stone tools. Phytolitharien, 15: 2-8. 
Costin, C. L. 1991, Craft specialization: issues in defining, documenting, and explaining the organization of production. Archaeological Method and Theory, 3: 1-56.

URL: http://www.jstor.org/stable/20170212

Frachetti, M.D. 2008, Pastoralist Landscapes and Social Interaction in Bronze Age Eurasia. University of California Press, Berkeley, 213 p.

Günchinsüren, B. 2009, Introduction into Stone Age of Mongolia. In: Current Archaeological Research in Mongolia. Papers from the First International Conference on Archaeological Research in Mongolia, held in Ulaanbaatar August 19-23 ${ }^{\text {rd }}, 2007$ (Parzinger, H., Pohl, E., \& Tseveendorzh, D., Eds.), Contributions to Asian Archaeology Vol. 8, Vor- und Frühgeschichtliche Archäologie, Bonn: p. 21-26.

Günchinsüren, B., \& Bazagür, D. 2009, An outline of Neolithic studies in Mongolia. In: Current Archaeological Research in Mongolia. Papers from the First International Conference on Archaeological Research in Mongolia, held in Ulaanbaatar August 1923 ${ }^{\text {rd }}$, 2007 (Parzinger, H., Pohl, E., \& Tseveendorzh, D., Eds.), Contributions to Asian Archaeology Vol. 8, Vor- und Frühgeschichtliche Archäologie, Bonn: p. 47- 52.

Henry, A.G., Hudson, H.F., \& Piperno, D.R. 2009, Changes in starch grain morphologies from cooking. Journal of Archaeological Science, 36(3): 915-922. doi:10.1016/j.jas.2008.11.008

Janz, L. 2012, Chronology of Post-Glacial Settlement in the Gobi Desert and the Neolithization of Arid Mongolia and China. Unpublished Ph.D. dissertation, University of Arizona, 524 p. URL: http://hdl.handle.net/10150/223342

Janz, L., Elston, R., \& Barr, J. 2009, Radiocarbon evidence for the Holocene survival of the East Asian Ostrich and implications for dating surface assemblages in the Gobi Desert. Journal of Archaeological Science, 36(9): 1982-1989. doi:10.1016/j.jas.2009.05.012

Lees, S.H., \& Bates, D.G. 1974, The origins of specialized nomadic pastoralism: a systematic model. American Antiquity, 39(2): 187-193. doi:10.2307/279581

Majigsuren, Y., \&Treworgy, J.D. 2011, Geology. In: Ikh Nart Nature Reserve, Nature Guide 4, ECO nature edition, (Reading, R., Kenny, D., \& Steinbauer-Burkart, D., Eds.), Steinbauer-Burkart OHG, Oberaula: p. 6-7.

Reading, R., Kenny, D., \&Steinbauer-Burkart, D., (Eds.) 2011, Ikh Nart Nature Reserve, 2nd Edition. Nature-Guide No. 4, Mongolia. ECO Nature Edition Steinhauer-Burkart OHG, Oberaula, p. 64.

Schneider, J.S. 2002, Stone textures and function: a relationship between milling tools and subsistence as derived from western American quarries data. In: Asmosia 5, Interdisciplinary Studies on Ancient Stone. Proceedings of the fifth international conference of the Association for the Study of Marble and Other Stones in Antiquity, Museum of Fine Arts, Boston, June 1998, (Herrmann, J., Herz, N., \& Newman, R., Eds.), Archetype Publications, London: p. 381-393.

Schneider, J.S. \& Tserendagva, Y. (2013). A First View of a Mongolian Archaeological Landscape in the East Gobi Desert: Preliminary Results from an In-Progress-RandomSample Inventory within Ikh Nartiin Chuluu Nature Reserve. presented at the $78^{\text {th }}$ Annual Meeting of the Society for American Archaeology, 3-7 April 2013, Honolulu. 
Tserendagva, Y., Dalantai, S., \& Schneider, J. 2015, Brief results of the joint MongolianAmerican expedition for archaeological study at Ikh Nart Nature Reserve. In: МОНГОАЬІН АРХЕОАОГИ2014 (Mongolian Archaeology 2014), Institute of Archaeology, Mongolian Academy of Sciences, Ulaanbaatar: p. 41-45.

Tserendagva, Y., \& Schneider J.S. 2014, Brief results of the joint Mongolian-American expedition for archaeological study at Ikh Nart Nature Reserve. In: МОНГОАЬН АРХЕОАОГИ2013, (Mongolian Archaeology 2013), Institute of Archaeology, Mongolian Academy of Sciences, Ulaanbaatar: p. 23-27.

Wright, J. 2006, The Adoption of Pastoralism in Northeast Asia, Monumental Transformation in the EgiinGol Valley, Mongolia. Unpublished Ph.D. dissertation, Harvard University, Cambridge, $382 \mathrm{p}$.

Wright, J., \&Janz, L. 2012, The Younger Dryas in Arid Northeast Asia. In: Hunter-Gatherer Behavior: Human Response during the Younger Dryas, (Eren, M., Ed.), Left Coast Press, Walnut Grove: p. 231-247. 